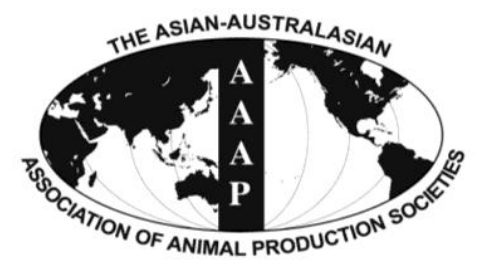

Asian-Aust. J. Anim. Sci.

Vol. 26, No. 2 : 241-246 February 2013

http://dx.doi.org/10.5713/ajas.2012.12434

www.ajas.info

pISSN 101 1-2367 elSSN 1976-5517

\title{
Effect of Vitamin Levels and Different Stocking Densities on Performance, Nutrient Digestibility, and Blood Characteristics of Growing Pigs
}

\author{
Z. F. Zhang ${ }^{1}$, J. Li ${ }^{1}$, J. C. Park ${ }^{2}$ and I. H. Kim ${ }^{1}$, \\ ${ }^{1}$ Department of Animal Resource and Science, Dankook University, \\ No. 29 Anseodong, Cheonan, Choongnam, 330-714, Korea \\ ${ }^{2}$ National Institute of Animal Science, Rural Development Administration of Korea, Korea
}

\begin{abstract}
This study was conducted to evaluate the effects of dietary vitamin levels and stocking densities on growth performance, nutrient digestibility, and blood characteristics in growing pigs. A $2 \times 3$ factorial (two vitamin levels, three regimens of stocking densities) arrangement was utilized with 96 pigs $(23.10 \pm 0.95 \mathrm{~kg}$ initial body weight and $63 \mathrm{~d}$ of age $)$ for $36 \mathrm{~d}$. The pigs were allocated to pens with different stocking density $\left(0.64,0.48\right.$, and $0.38 \mathrm{~m}^{2} / \mathrm{pig}$, respectively). The diets used in this study were a normal diet (based on NRC) and a high level of vitamin diet (2-fold higher than normal diet). The ADG and ADFI of pigs were decreased as the stocking density increased $(p=0.03$ and $p=0.01$, respectively). The $\mathrm{G} / \mathrm{F}$ of pigs was $5 \%$ lower in the high vitamin treatment $(\mathrm{p}=0.03)$ as compared with the control treatment. The apparent total tract digestibility (ATTD) of DM and $\mathrm{N}$ digestibility was negatively affected by the high level of vitamin in diets ( $p=0.05$ and $p=0.04$, respectively). Moreover, a significant and negative effect on the ATTD of N was detected in the large groups (linear, $\mathrm{p}=0.02$ ). Blood cortisol concentration was increased with increasing stocking density (linear, $p=0.05)$, and was decreased by high level of vitamin $(p=0.04)$ at the end of this experiment. Stocking density also caused a linear reduction in WBC concentration $(\mathrm{p}=0.05)$. Our data indicated that the principal effect of stocking density was not reliant on dietary vitamin levels. In conclusion, results indicated that doubling the vitamin supplementation did not improve the growth performance of pigs in high density. However, the blood cortisol concentration was decreased but the ATTD of $\mathrm{N}$ digestibility was impaired by high level of vitamin diet. (Key Words: Cortisol, Density, Growing pigs, Performance, Vitamin Level)
\end{abstract}

\section{INTRODUCTION}

Stocking density (i.e., the number of animals per pen) is an important determinant of barn design. Growth performance of pigs housed individually in ideal experimental environments is generally higher than that of their commercial group-housed counterparts (Kerr et al., 2005). Previous researches based on traditional nursery and growing-finishing facilities focused on determining the relationship between stocking rate and animal growth performance, thus to determine the optimum floor space required both for maximum individual animal performance and facility output (Kornegay and Notter, 1984; Brumm et al., 2001). The majority of studies on the effect of stocking density of pigs have claimed that the optimum space

\footnotetext{
* Corresponding Author: In Ho Kim. Tel: +82-41-550-3652, Fax: +82-41-565-2949, E-mail: inhokim@ dankook.ac.kr Submitted Aug. 11, 2012; Accepted Oct. 5, 2012; Revised Oct. 15, 2012
}

allowances for rearing pigs were 0.56 to $0.78 \mathrm{~m}^{2} / \mathrm{pig}$. However, this density is significantly lower than in typical experimental and small commercial operations.

Stocking density has a significant impact on growth performance of pigs. Previously studies have been reported that body weight gain and feed intake were decreased when pigs were raised in pens with high stocking density compared with those bred in low stocking density pens (Gonyou and Stricklin, 1998; Brumm et al., 2001; White et al., 2008; Cho et al., 2010).

A reduction in daily feed intake in higher stocking density would result in a reduction in the daily intake of nutrients, including vitamins. Dietary supplementation with vitamins has been shown to diminish stress of animals such as undergoing vibration stimulation of transport and high ambient temperature (Sahin et al., 2003; Peeters et al., 2004; Peeters et al., 2005). Thus, it can be hypothesized that pigs in higher stocking density will respond more positively 
to the addition of vitamins as compared with those in lower stocking density. In order to assess this hypothesis, the present study was conducted in an effort to assess the effects of different dietary vitamin levels and different stocking densities on growth performance, nutrient digestibility, and blood characteristics in growing pigs.

\section{MATERIALS AND METHODS}

\section{Experimental design, animals, housing and diets}

All animals received human care as outlined in the Guide for the Care and Use of Experimental Animals (Dankook University, Animal Care Committee).

A total of 96 ((Landrace $\times$ Yorkshire $) \times$ Duroc $)$ pigs with an average initial body weight $(\mathrm{BW})$ of $23.10 \pm 0.95 \mathrm{~kg}$ were used in a $2 \times 3$ factorial trial to determine the primary effects and interactions of stocking density $(0.64,0.48$, and 0.38 $\mathrm{m}^{2} /$ pig, pen size $1.6 \times 1.2 \mathrm{~m}$ ) and dietary vitamin levels (common or high vitamin diet). The pigs were allotted to 4 replicate pens per treatment. The experiments were conducted for 36 days at the university's swine research farm. At the beginning of the experiment, the pigs were allotted based on initial BW in accordance with a completely randomized design. Each pen was furnished with one nipple waterer and one two-hole self feeder. According to previous researches (Kornegay and Notter, 1984; Brumm et al., 2001), the optimum stocking density for growing pigs is 0.56 to $0.78 \mathrm{~m}^{2} / \mathrm{pig}$. Ten and fourteen pigs per pen were utilized in that experiment. However, small group sizes are usually operated in the typical experimental condition. So in the current study we reduced the number of pigs per pen, but kept the stocking density to fit the optimum density or higher than it. The floor-space allowances for all treatments were, $0.64 \mathrm{~m}^{2} / \mathrm{pig}$ (uncrowded), $0.48 \mathrm{~m}^{2} / \mathrm{pig}$ (slightly crowded), and 0.38 $\mathrm{m}^{2} /$ pig (crowded) with 3,4 and 5 pigs per pen respectively. The number of pigs per pen is reduced as compared with previous research, while the stocking density fits or higher than the optimum density $\left(0.38\right.$ to $0.64 \mathrm{~m}^{2} / \mathrm{pig}$ vs 0.56 to $0.78 \mathrm{~m}^{2} / \mathrm{pig}$ ).

The composition of the control and high vitamin diets are summarized in Table 1. The normal diets were provided in mash form and were formulated to meet or exceed the NRC (1998) recommendations for all nutrients. The high vitamin diet provided 2-fold higher vitamin than the normal diet. Feed and water were available ad libitum throughout the experimental period. The pigs were housed in an environmentally-controlled room with an average temperature of $24^{\circ} \mathrm{C}$. The lights remained on from 06:00 am to $24: 00$ pm each day.

\section{Sampling and measurements}

Body weight and feed intake were measured at d 0,18 ,
Table 1. Compositions of experimental diets (as-fed basis)

\begin{tabular}{|c|c|c|}
\hline Items & $\begin{array}{c}\text { Control } \\
\text { diet }\end{array}$ & $\begin{array}{c}\text { High vitamin } \\
\text { diet }\end{array}$ \\
\hline \multicolumn{3}{|l|}{ Ingredients $(\mathrm{g} / \mathrm{kg})$} \\
\hline Maize & 660.0 & 658.8 \\
\hline Soybean meal (CP 47.5\%) & 239.6 & 239.6 \\
\hline Animal fat & 42.4 & 42.4 \\
\hline Molasses & 30.0 & 30.0 \\
\hline Dicalcium phosphate & 12.6 & 12.6 \\
\hline Salt & 2.5 & 2.5 \\
\hline Limestone & 10.1 & 10.1 \\
\hline Vitamin premix $^{\mathrm{a}, \mathrm{b}}$ & 1.2 & 2.4 \\
\hline Trace mineral premix ${ }^{c}$ & 1.0 & 1.0 \\
\hline L-lysine-HCL & 0.1 & 0.1 \\
\hline Antioxidant, Ethoxyquin $25 \%$ & 0.5 & 0.5 \\
\hline \multicolumn{3}{|l|}{ Chemical composition $(\mathrm{g} / \mathrm{kg})$} \\
\hline $\mathrm{ME}(\mathrm{MJ} / \mathrm{kg})$ & 14.1 & 14.1 \\
\hline Crude protein & 180.0 & 180.0 \\
\hline Lysine & 9.0 & 9.0 \\
\hline Methionine & 2.8 & 2.8 \\
\hline Calcium & 7.0 & 7.0 \\
\hline Phosphorus & 6.0 & 6.0 \\
\hline \multicolumn{3}{|l|}{ Analyzed composition $(\mathrm{g} / \mathrm{kg})$} \\
\hline Crude protein & 176.0 & 175.8 \\
\hline Lysine & 11.1 & 10.9 \\
\hline Methionine & 3.1 & 3.0 \\
\hline Calcium & 7.6 & 7.4 \\
\hline Phosphorus & 6.4 & 6.2 \\
\hline
\end{tabular}

${ }^{a}$ Control diet provided per $\mathrm{kg}$ of complete diet: 10,000 IU vitamin A, 2,000 IU vitamin $D_{3}, 40$ IU vitamin $E, 100 \mathrm{mg}$ vitamin C, $10 \mathrm{mg}$ vitamin $\mathrm{K}_{3}, 10 \mathrm{mg}$ vitamin $\mathrm{B}_{2}, 2 \mathrm{mg}$ vitamin $\mathrm{B}_{6}, 25 \mathrm{mg}$ pantothenic acid, $50 \mathrm{mg}$ niacin and $0.04 \mathrm{mg}$ biotin.

${ }^{\mathrm{b}} \mathrm{High}$ vitamin diet provided per kg of complete diet: 20,000 IU vitamin A, 4,000 IU vitamin $D_{3}, 80 \mathrm{IU}$ vitamin $\mathrm{E}, 200 \mathrm{mg}$ vitamin C, $20 \mathrm{mg}$ vitamin $\mathrm{K}_{3}, 20 \mathrm{mg}$ vitamin $\mathrm{B}_{2}, 4 \mathrm{mg}$ vitamin $\mathrm{B}_{6}, 50 \mathrm{mg}$ pantothenic acid, $100 \mathrm{mg}$ niacin and $0.08 \mathrm{mg}$ biotin.

${ }^{c}$ Provided per kg of complete diet: Mn, $12.5 \mathrm{mg}$; Zn, $179 \mathrm{mg}$; Cu, $5 \mathrm{mg}$; I, $0.5 \mathrm{mg}$; Se, $0.4 \mathrm{mg}$.

and 36 in an effort to determine average daily gain (ADG), average daily feed intake (ADFI), and gain/feed (G/F) ratio. Chromic oxide $\left(\mathrm{Cr}_{2} \mathrm{O}_{3}\right)$ was added $(0.2 \%)$ as an indigestible marker from d 28 to 36 . Feed and fresh fecal samples from each pen were collected on $d$ 36. The feed and fecal samples were analyzed for dry matter (DM) and nitrogen (N) digestibility (AOAC, 1995). Chromium was determined via UV absorption spectrophotometry (UV-1201, Shimadzu, Japan), and the apparent digestibility of DM and $\mathrm{N}$ was calculated via the indirect method.

Blood samples were acquired from the cervical vein into both $\mathrm{K}_{3}$ EDTA vacuum tubes and clot activator vacuum tubes (Becton-Dickinson Vacutainer Systems, Franklin Lakes, NJ, USA) from 2 pigs in each pen at d 18 and 36. Both the concentrations of white blood cells (WBC) and lymphocytes in whole blood, and $\mathrm{IgG}$, cortisol, blood urea nitrogen (BUN), epinephrine, and norepinephrine were 
Table 2. Effects of dietary vitamin level and stocking density on performance of growing pigs

\begin{tabular}{|c|c|c|c|c|c|c|c|c|c|c|}
\hline \multirow{3}{*}{ Items } & \multirow{2}{*}{\multicolumn{3}{|c|}{ Stocking density $\left(\mathrm{m}^{2} / \mathrm{pig}\right)$}} & \multirow{3}{*}{ SEM } & \multirow{2}{*}{\multicolumn{2}{|c|}{$\operatorname{Diet}^{\mathrm{a}}$}} & \multirow{3}{*}{ SEM } & \multicolumn{3}{|c|}{ p-values ${ }^{c}$} \\
\hline & & & & & & & & \multirow{2}{*}{ Diet } & \multicolumn{2}{|c|}{ Stocking density } \\
\hline & 0.64 & 0.48 & 0.38 & & $\mathrm{CON}$ & HVD & & & $\mathrm{L}^{\mathrm{b}}$ & $\mathrm{Q}^{\mathrm{b}}$ \\
\hline \multicolumn{11}{|l|}{ Day 0 to 18} \\
\hline $\mathrm{ADG}(\mathrm{g})$ & 562 & 561 & 538 & 23 & 568 & 539 & 29 & 0.40 & 0.01 & 0.21 \\
\hline ADFI (g) & 1,102 & 1,077 & 1,063 & 37 & 1,098 & 1,063 & 44 & 0.75 & $<0.01$ & 0.15 \\
\hline $\mathrm{G} / \mathrm{F}$ & 0.51 & 0.52 & 0.51 & 0.01 & 0.52 & 0.51 & 0.01 & 0.46 & 0.18 & 0.01 \\
\hline \multicolumn{11}{|l|}{ Day 19 to 36} \\
\hline $\mathrm{ADG}(\mathrm{g})$ & 841 & 758 & 709 & 47 & 807 & 729 & 49 & 0.07 & 0.07 & 0.14 \\
\hline ADFI $(g)$ & 1,372 & 1,347 & 1,281 & 62 & 1,357 & 1,309 & 63 & 0.16 & 0.01 & 0.11 \\
\hline $\mathrm{G} / \mathrm{F}$ & 0.61 & 0.56 & 0.55 & 0.03 & 0.60 & 0.56 & 0.03 & 0.06 & 0.03 & 0.12 \\
\hline \multicolumn{11}{|l|}{ Day 0 to 36} \\
\hline ADG (g) & 701 & 659 & 617 & 26 & 685 & 632 & 22 & 0.12 & 0.03 & 0.23 \\
\hline ADFI (g) & 1,237 & 1,212 & 1,172 & 37 & 1,227 & 1,186 & 31 & 0.35 & 0.01 & 0.18 \\
\hline $\mathrm{G} / \mathrm{F}$ & 0.57 & 0.54 & 0.53 & 0.02 & 0.56 & 0.53 & 0.02 & 0.03 & 0.10 & 0.26 \\
\hline
\end{tabular}

${ }^{\mathrm{a}} \mathrm{CON}=$ Control diet; HVD = High vitamin diet. ${ }^{\mathrm{b}}$ p-values for linear (L) and quadratic (Q) effects for stocking density.

${ }^{\mathrm{c}}$ Main effects of stocking density and vitamin. Interactions between main effects were not significant and were not shown in the table.

measured in the serum. All blood parameters (WBC and lymphocytes) and serum parameters (IgG, BUN, cortisol, epinephrine and norepinephrine) were measured using an automatic blood analyzer (ADVIA 120, Bayer, USA).

\section{Statistical analyses}

All data were analyzed as a completely randomized design with a $2 \times 3$ factorial arrangement of treatments by using the GLM procedure, as outlined by SAS (1996). The pen was established as the experimental unit during the feeding period, whereas individual pig was considered to be the experimental unit for nutrient digestibility and blood characteristics. Additionally, orthogonal comparisons were made using polynomial regression to determine the linear and quadratic effects of increasing stocking density. Statements of statistical significance were based on $\mathrm{p}<0.05$.

\section{RESULTS}

No significant interactions between dietary vitamin level and stocking density treatments were observed for the growth performance, nutrient digestibility, or blood characteristics of the growing pigs. Thus, such data are not presented herein.

Table 2 presented the growth performance observed in the current experiment. During d 0 to 18 , the ADG ( $\mathrm{p}=$
$0.01)$ and ADFI $(\mathrm{p}<0.01)$ were linearly reduced with increasing stocking density. While $\mathrm{G} / \mathrm{F}$ showed a quadratic effect $(\mathrm{p}=0.01)$ by stocking density. Pigs reared in pens with density of $0.48 \mathrm{~m}^{2} /$ pig had higher $\mathrm{G} / \mathrm{F}$ ratio $(0.52)$ than pigs bred in pens with densities of 0.64 and $0.38 \mathrm{~m}^{2} / \mathrm{pig}$ (0.51 and 0.51 , respectively). From d 19 to 36 , ADFI ( $\mathrm{p}=$ $0.01)$ and $\mathrm{G} / \mathrm{F}(\mathrm{p}=0.03)$ were linearly decreased with increasing stocking density. During the entire trial, the ADG $(p=0.03)$ and ADFI $(p=0.01)$ of the pigs were linearly reduced with increasing stocking density. We noted no effects ( $p>0.05)$ of vitamin level on ADG and ADFI. However, for the overall period, the G/F of pigs was $5 \%$ lower $(\mathrm{p}=0.03)$ in the high vitamin treatment as compared with the control treatment.

Nutrient digestibility at the end of this trial is provided in Table 3. The ATTD of DM and $\mathrm{N}$ was decreased significantly by the high vitamin level treatments $(\mathrm{p}=0.05$, $\mathrm{p}=0.04)$. Moreover, the ATTD of $\mathrm{N}$ was decreased as the stocking density increased (linear, $\mathrm{p}=0.02$ ).

At the beginning of the trial ( $d 0$ ), no significant differences among the treatments were observed in any of the blood characteristics tested (Table 4). On d 18, the cortisol concentration was increased by stocking density (linear, $\mathrm{p}=0.02$ ), and the main effect of dietary vitamin level were observed, cortisol concentrations were decreased by high level of vitamin $(p=0.04)$ at the end of this

Table 3. Effects of dietary vitamin level and stocking density on the nutrients digestibility of growing pigs

\begin{tabular}{|c|c|c|c|c|c|c|c|c|c|c|}
\hline \multirow{3}{*}{ Items $(\%)$} & \multirow{2}{*}{\multicolumn{3}{|c|}{ Stocking density $\left(\mathrm{m}^{2} / \mathrm{pig}\right)$}} & \multirow{3}{*}{ SEM } & \multirow{2}{*}{\multicolumn{2}{|c|}{ Diet $^{\mathrm{a}}$}} & \multirow{3}{*}{ SEM } & \multicolumn{3}{|c|}{ p-values ${ }^{c}$} \\
\hline & & & & & & & & \multirow{2}{*}{ Diet } & \multicolumn{2}{|c|}{ Stocking density } \\
\hline & 0.64 & 0.48 & 0.38 & & $\mathrm{CON}$ & HVP & & & $\mathrm{L}^{\mathrm{b}}$ & $Q^{b}$ \\
\hline Dry matter & 78.37 & 78.36 & 78.11 & 0.25 & 79.91 & 76.97 & 1.33 & 0.05 & 0.11 & 0.21 \\
\hline Nitrogen & 78.10 & 77.67 & 76.55 & 1.17 & 79.40 & 75.45 & 1.29 & 0.04 & 0.02 & 0.35 \\
\hline
\end{tabular}

${ }^{\mathrm{a}} \mathrm{CON}=$ Control diet; HVD = High vitamin diet. ${ }^{\mathrm{b}} \mathrm{p}$-values for linear (L) and quadratic (Q) effects for stocking density.

${ }^{\mathrm{c}}$ Main effects of stocking density and vitamin. Interactions between main effects were not significant and were not shown in the table. 
Table 4. Effects of dietary vitamin level and stocking density on blood characteristics of growing pigs

\begin{tabular}{|c|c|c|c|c|c|c|c|c|c|c|}
\hline \multirow{3}{*}{ Items } & \multirow{2}{*}{\multicolumn{3}{|c|}{ Stocking density $\left(\mathrm{m}^{2} / \mathrm{pig}\right)$}} & \multirow{3}{*}{ SEM } & \multirow{2}{*}{\multicolumn{2}{|c|}{ Diet $^{\mathrm{a}}$}} & \multirow{3}{*}{ SEM } & \multicolumn{3}{|c|}{ p-values ${ }^{c}$} \\
\hline & & & & & & & & \multirow{2}{*}{ Diet } & \multicolumn{2}{|c|}{ Stocking density } \\
\hline & 0.64 & 0.48 & 0.38 & & $\mathrm{CON}$ & HVP & & & $\mathrm{L}^{\mathrm{b}}$ & $\mathrm{Q}^{\mathrm{b}}$ \\
\hline Observed pigs & 24 & 32 & 40 & & 48 & 48 & & & & \\
\hline \multicolumn{11}{|l|}{ BUN (mg/dl) } \\
\hline Initial & 14.5 & 15.0 & 14.6 & 0.6 & 14.7 & 14.7 & 0.6 & 0.63 & 0.53 & 0.62 \\
\hline Day 18 & 14.6 & 14.8 & 14.4 & 0.3 & 14.9 & 14.3 & 0.3 & 0.25 & 0.80 & 0.75 \\
\hline Day 36 & 18.0 & 17.6 & 16.8 & 0.2 & 18.4 & 16.9 & 0.7 & 0.07 & 0.03 & 0.40 \\
\hline \multicolumn{11}{|l|}{$\operatorname{IgG}(\mathrm{mg} / \mathrm{dl})$} \\
\hline Initial & 936 & 951 & 963 & 22 & 950 & 952 & 4 & 0.72 & 0.55 & 0.32 \\
\hline Day 18 & 1,075 & 1,058 & 970 & 77 & 1,044 & 1,025 & 18 & 0.90 & 0.52 & 0.80 \\
\hline Day 36 & 1,037 & 960 & 1,020 & 65 & 1,009 & 1,002 & 6 & 0.87 & 0.95 & 0.59 \\
\hline \multicolumn{11}{|l|}{ Cortisol $(\mu \mathrm{g} / \mathrm{dl})$} \\
\hline Initial & 3.46 & 3.71 & 3.96 & 0.34 & 3.73 & 3.69 & 0.03 & 0.07 & 0.52 & 0.14 \\
\hline Day 18 & 2.42 & 3.10 & 3.34 & 0.28 & 3.08 & 2.82 & 0.11 & 0.05 & 0.02 & 0.23 \\
\hline Day 36 & 3.64 & 3.92 & 4.54 & 0.29 & 4.20 & 3.79 & 0.16 & 0.04 & 0.05 & 0.40 \\
\hline \multicolumn{11}{|l|}{$\operatorname{WBC}\left(10^{3} / \mathrm{mm}^{3}\right)$} \\
\hline Initial & 18.77 & 17.78 & 18.85 & 1.00 & 18.55 & 18.34 & 0.14 & 0.93 & 0.99 & 0.55 \\
\hline Day 18 & 22.16 & 21.89 & 21.93 & 0.26 & 21.03 & 22.95 & 1.59 & 0.37 & 0.92 & 0.94 \\
\hline Day 36 & 23.04 & 20.46 & 19.94 & 1.08 & 20.22 & 22.07 & 1.11 & 0.15 & 0.05 & 0.46 \\
\hline \multicolumn{11}{|l|}{ Lymphocyte (\%) } \\
\hline Initial & 54.33 & 52.83 & 53.60 & 1.34 & 51.71 & 55.47 & 2.63 & 0.23 & 0.70 & 0.90 \\
\hline Day 18 & 54.67 & 53.08 & 54.33 & 1.37 & 56.72 & 51.67 & 3.75 & 0.11 & 0.88 & 0.81 \\
\hline Day 36 & 57.89 & 52.83 & 51.75 & 3.90 & 53.69 & 54.62 & 0.88 & 0.30 & 0.12 & 0.49 \\
\hline \multicolumn{11}{|c|}{ Epinephrine (pg/ml) } \\
\hline Initial & 96.73 & 99.36 & 97.89 & 2.12 & 97.29 & 97.94 & 0.23 & 0.59 & 0.26 & 0.17 \\
\hline Day 18 & 96.52 & 97.93 & 92.76 & 4.23 & 94.40 & 90.88 & 3.25 & 0.87 & 0.46 & 0.99 \\
\hline Day 36 & 92.67 & 99.51 & 92.44 & 5.03 & 93.38 & 95.78 & 1.55 & 0.84 & 0.97 & 0.17 \\
\hline \multicolumn{11}{|c|}{ Norepinephrine (pg/ml) } \\
\hline Initial & 809 & 793 & 824 & 23 & 812 & 806 & 4 & 0.29 & 0.37 & 0.92 \\
\hline Day 18 & 793 & 885 & 868 & 75 & 838 & 859 & 17 & 0.45 & 0.55 & 0.85 \\
\hline Day 36 & 852 & 821 & 815 & 35 & 841 & 818 & 25 & 0.29 & 0.86 & 0.94 \\
\hline
\end{tabular}

${ }^{a} \mathrm{CON}=$ Control diet; HVD = High vitamin diet. ${ }^{\mathrm{b}}$ p-values for linear (L) and quadratic (Q) effects for stocking density.

${ }^{\mathrm{c}}$ Main effects of stocking density and vitamin. Interactions between main effects were not significant and were not shown in the table.

experiment. Similarly, a linear effect $(p=0.05)$ of stocking density and the main effect of vitamin level were also observed at the end of the experiment. Blood urea nitrogen concentration was found to be influenced by stocking density in a linear fashion $(p=0.03)$ with the highest concentration in the 3 pigs/pen treatment group at the end of the experiment. Stocking density also induced a linear increase in WBC concentration at d $36(\mathrm{p}=0.05)$. Lymphocyte and $\mathrm{IgG}$ concentrations, as well as epinephrine and norepinephrine concentrations, were unaffected by stocking density or dietary vitamin levels during each of the dietary phases.

\section{DISCUSSION}

Previous studies of stocking density have yielded inconsistent results. Gonyou and Stricklin (1998) determined that ADFI and ADG were reduced with increasing stocking density $\left(0.030,0.039\right.$, and $0.048 \mathrm{~m}^{2} \times$ $\mathrm{BW}^{0.667}$ ) during the growing phases (25 to $60 \mathrm{~kg} \mathrm{BW}$ ). However, Krohn et al. (2000) reported that stocking density $\left(0.27,0.44\right.$, and $\left.0.52 \mathrm{~m}^{2} / \mathrm{pig}\right)$ had no effect on minipig performance. Brumm et al. (2001) reported that no residual effects of nursery crowding on growth performance during growing-finishing period. Gonyou et al. (1992) reported a substantial reduction in body weight gain and feed intake for pigs in groups of five as compared with the individually penned pigs. In a subsequent study, reduction in ADG and ADFI was less profound when group size was increased (3, $5,6,7,10$, and 15 pigs per pen) with increasing stocking density $\left(0.030,0.039\right.$, and $0.048 \mathrm{~m}^{2} \times \mathrm{BW}^{0.667}$ ) (Gonyou and Stricklin, 1998). Also, Kornegay and Notter (1984) calculated gain reductions of $0.3 \%$ per pig increase in stocking density, for growing pigs, on the basis of their 
literature review. It was consistent with the date reported in the current experiment. Hyun and Ellis (2001) and Nielsen and Lawrence (1993) reported that the percentage of time that the feeder was occupied increased with increasing stocking density. In our study, the ADFI and ADG were decreased with increasing stocking density, and it is generally thought that the reduction in body weight gain is the consequence of reductions in feed intake. Also, the inconsistent results provided in the previous study may have been caused by different feeder types, namely our study and two-hole feeder (Gonyou et al., 1992) vs the single-space feeder (Walker, 1991). As Gonyou et al. (1992) reported that pigs in groups avoided eating when another pig was using the two-hole feeder, and suggested that this behavior may result in reduced feed intake. An alternative hypothesis, which was previously put forward by Chapple (1993), is that stress within larger groups reduces growth potential, and hence $\mathrm{ADG}$, which in turn reduces appetite and ADFI. Stress within the group might be the result of physical restrictions, as discussed above, or from the social stress inherent to interaction with more pigs. In the first period of the experiment ( $\mathrm{d} 0$ to 18 ), the $\mathrm{G} / \mathrm{F}$ ratio was higher $(\mathrm{p}=0.01)$ in $4 \mathrm{pigs} / \mathrm{pen}\left(0.48 \mathrm{~m}^{2} / \mathrm{pig}\right)$ treatment compared with 3 and 5 pigs/pen $\left(0.64\right.$ and $0.38 \mathrm{~m}^{2} / \mathrm{pig}$, respectively), which meant that at the beginning of growing phase, density of $0.48 \mathrm{~m}^{2} / \mathrm{pig}$ was as comfortable as 0.64 $\mathrm{m}^{2} / \mathrm{pig}$ for growing pigs with body weight of $23.10 \mathrm{~kg}$. However, in the second (d 19 to 36) and entire (d 0 to 36) period, the highest $\mathrm{G} / \mathrm{F}$ was observed in 3 pigs/pen $(0.64$ $\mathrm{m}^{2} / \mathrm{pig}$ ) treatment. This result indicated that lower stocking density related with higher feed conversion rate. Similar to what was reported by Yen and Pond (1987), no interaction effects were observed between dietary treatments and stocking density in the growth performance of pigs.

Vitamin E was reported to exert no influence on daily feed intake. Peeters et al. (2005) observed no difference in feeding characteristics between the negative control and vitamin E-supplemented treatment (120 ppm) groups for a period of $21 \mathrm{~d}$. In that experiment, vitamin $\mathrm{C}$ supplementation did not affect water and feed intake throughout the trials. Multi-vitamin used in the present study was 2-fold higher than normal diet in each kind of vitamin, so the effect caused by high level vitamin diet might not only be due to these two vitamins. More researches are needed to investigate the effects of each single vitamin.

Social interactions have a profound effect on the pituitary adrenocortical (PAC) and the sympathetic adrenomedullary (SAM) systems (Sachser, 1994). The longterm hyper activation of both the SAM and the PAC systems is associated with the etiology of irreversible injury and even death (Henry, 1982). Blood glucocorticoid concentrations-cortisol being the principal component in animals and man-can be utilized as a measure of PAC activity; serum catecholamine concentrations-epinephrine and norepinephrine are reliable indicators of SAM activity.

Cortisol is the primary glucocorticoid released during times of stress in pigs (Kojima et al., 2009). The concentration of cortisol increased because of the stress associated with transportation, social mixing, and maternal separation (Cooper et al., 2009). In our study, the linearly increased cortisol concentration evidenced higher stress in the $5 \mathrm{pigs} / \mathrm{pen}\left(0.38 \mathrm{~m}^{2} / \mathrm{pig}\right)$ group than in the $3 \mathrm{pigs} / \mathrm{pen}$ $\left(0.64 \mathrm{~m}^{2} / \mathrm{pig}\right)$ group. Furthermore, this linear increase in cortisol concentration exerted a negative effect on immunity-associated blood cell (WBC) production. However, IgG and lymphocytes, two other immunityassociated items, were not shown to be affected by increases in cortisol concentration. Surprisingly, it remains unclear as to why these 3 response criteria followed different patterns in our study. More research will be required in order to elucidate this phenomenon.

In our study, epinephrine and norepinephrine concentrations were unaffected by stocking density or dietary vitamin levels. From the lack of variation of epinephrine and norepinephrine level and the linear increase in cortisol concentration, we can conclude that larger stocking densities can stimulate pituitary, but not sympathetic activity. Research conducted with humans and rodents showed that it is psychological stress, rather than physical stress, which constitutes the more potent stressor (Dantzer and Mormède, 1983). Provide $0.38 \mathrm{~m}^{2}$ for each pig could be considered to be a tenser environment for pigs. This would explain why the highest cortisol concentrations were found in the most crowded treatment in our experiment.

The significant reduction in DM and $\mathrm{N}$ digestibility with increasing stocking density, in the current experiment, can be explained in that the pigs in larger groups experience higher levels of social stress, which negatively affects nutrient digestibility. Both the linear effects of BUN and $\mathrm{N}$ digestibility at the end of the experiment showed that poor $\mathrm{N}$ utilization was caused by social stress. Lower BUN was found when $\mathrm{N}$ utilization was impaired (Borg et al., 1978; Cole, 1992), which indicated the similar result in the present study.

In our study, we did not observed any improvement in growth performance by increasing dietary vitamin level in pigs with high stocking density. In agreement with observations made in channel catfish (Gatlin et al., 1986), dietary supplementation with vitamin $\mathrm{C}$ and $\mathrm{D}$ did not improve growth performance.

\section{CONCLUSIONS}

In conclusion, impaired daily gain was associated with 
reductions of daily feed intake caused by higher social stress in larger groups. Furthermore, additional vitamin supplementation did not overcome this reduction of daily gain, as we had expected. However, blood cortisol status was improved but $\mathrm{N}$ digestibility was decreased by high level of vitamin diet.

\section{ACKNOWLEDGEMENT}

The authors would like to acknowledge the financial assistance (No. PJ0081212012 of Bio-Green 21 and PJ006377 of FTA project) provided by the Rural Development Administration of Korea.

\section{REFERENCES}

AOAC. 1995. Official method of the analysis of the association of official analytical chemists, 16th edn. Washington, DC, USA.

Borg, B. S., G. W. Libal and R. C. Wahlstrom. 1987. Tryptophan and threonine requirements of young pigs and their effects on serum calcium, phosphorus and zinc concentrations. J. Anim. Sci. 64:1070-1078.

Brumm, M. C., M. Ellis, L. J. Johnston, D. W. Rozeboom and D. R. Zimmerman. 2001. Interaction of swine nursery and growfinish space allocations on performance. J. Anim. Sci. 79:1967-1972.

Chapple, R. P. 1993. Effect of stocking arrangement on pig performance. Manipul. Pig Prod. (Proc. 4th Bienn. Conf. Australas. Pig Sci. Assoc.). 4:87-97.

Cho, J. H., H. J. Monegue, M. D. Lindemann and G. L. Cromwell. 2010. Influence of crowding stress during the nursery period on growth performance of gilts and barrows. J. Anim. Sci. 88:736 (Abstr.).

Cole, N. A. 1992. Influence of postfast dietary crude protein and phosphorus content on nitrogen, phosphorus, calcium, and magnesium repletion in sheep. J. Anim. Sci. 70:2893-2900.

Cooper, T. A., M. P. Roberts, H. G. Kattesh and C. J. Kojima. 2009. Effects of transport stress, gender, and weaning weight on post-weaning performance in pigs. Prof. Anim. Sci. 25:189194.

Dantzer, R. and P. Mormède. 1983. Stress in farm animals: A need for reevaluation. J. Anim. Sci. 57:6-18.

Gatlin, D. M., W. E. Poe, R. P. Wilson, A. J. Ainsworth and P. R. Bowser. 1986. Effects of stockingdensity and vitamin C status on vitamin E-adequate and vitamin E-deficient fingerling channel catfish. Aquaculture 56:187-195.

Gonyou, H. W., R. P. Chapple and G. R. Frank. 1992. Productivity, time budgets and social aspects of eating in pigs penned in groups of five or individually. Appl. Anim. Behav. Sci. 34:291301.

Gonyou, H. W. and W. R. Stricklin. 1998. Effects of floor area allowance and group size on the productivity of growing/finishing pigs. J. Anim. Sci. 76:1326-1330.
Henry, J. P. 1982. The relation of social to biological processes in disease. Soc. Sci. Med. 16:369-380.

Hyun, Y. and M. Ellis. 2001. Effect of group size and feeder type on growth performance and feeding patterns in growing pigs. $\mathrm{J}$ Anim. Sci. 79:803-810.

Kerr, C. A., L. R. Giles, M. R. Jones and A. Reverter. 2005. Effects of grouping unfamiliar cohorts, high ambient temperature and stocking density on live performance of growing pigs. J. Anim. Sci. 83:908-915.

Kojima, C. J., S. J. Jenkins, T. A. Cooper, M. P. Roberts, J. A. Carroll and H. G. Kattesh. 2009. Effects of syndyphalin-33 on feed intake and circulating measures of growth hormone, cortisol, and immune cell populations in the recently weaned pig. J. Anim. Sci. 87:3218-3225.

Kornegay, E. T. and D. R. Notter. 1984. Effects of floor space and number of pigs per pen on performance. Pig News Info. 5:2333.

Krohn, T. C., L. Ellegaard and A. K. Hansen. 2000. A preliminary study of the impact of stocking density on the behaviour of group housed Göttingen Minipigs. Scand. J. Lab. Anim. Sci. 27:203-210.

Nielsen, B. L. and A. B. Lawrence. 1993. The effect of group size on the behavior and performance of growing pigs using computerized single-space feeders. Pig News Inform. 14:127129.

NRC. 1998. Nutrient requirement of swine, 10th rev. Natl. Acad. Press. Washington, DC, USA.

Peeters, E., B. Driessen, R. Steegmans, D. Henot and R. Geers. 2004. Effect of supplemental tryptophan, vitamin E, and a herbal product on responses by pigs to vibration. J. Anim. Sci. 82:2410-2420.

Peeters, E., A. Neyt, F. Beckers, S. De Smet, A. E. Aubert and R. Geers. 2005. Influence of supplemental magnesium, tryptophan, vitamin $\mathrm{C}$, and vitamin $\mathrm{E}$ on stress responses of pigs to vibration. J. Anim. Sci. 83:1568-1580.

Sachser, N. 1994. Social stratification and health in non-human mammals-a case study in guinea pigs. In: Social stratification and socioeconomic inequality (Ed. L. Ellis). Praeger, Westport. pp. 113-121.

Sahin, K., N. Sahin and O. Kucuk. 2003. Effects of chromium, and ascorbic acid supplementation on growth, carcass traits, serum metabolites, and antioxidant status of broiler chickens reared at a high ambient temperature $\left(32^{\circ} \mathrm{C}\right)$. Nutr. Res. 23:225-238.

SAS. 1996. SAS user's guide. Release 6. 12th edn. SAS Institute Inc., Cary, North Carolina, USA.

Walker, N. 1991. The effects on performance and behaviour of number of pigs per mono-place feeder. Anim. Feed Sci. Technol. 35:3-13.

White, H. M., B. T. Richert, A. P. Schinckel, J. R. Burgess, S. S. Donkin and M. A. Latour. 2008. Effects of temperature stress on growth performance and bacon quality in grow-finish pigs housed at two densities. J. Anim. Sci. 86:1789-1798.

Yen, J. T. and W. G. Pond. 1987. Effect of dietary supplementation with vitamin $\mathrm{C}$ or carbadox on weanling pigs subjected to crowding stress. J. Anim. Sci. 64:1672-1681. 